\title{
Dry matter production and chemical composition of Massai grass submitted to nitrogen rates and cutting heights
}

\section{Produção e composição bromatológica do capim Massai submetido a doses de nitrogênio e alturas de corte}

\author{
Giselle Abadia Campos Pereira ${ }^{1}$; Leni Rodrigues Lima ${ }^{1}$; Joelson Antonio Silva ${ }^{1}$; \\ Rosemary Laís Galati²; Joanis Tilemahos Zervoudakis²; Joadil Gonçalves de Abreu²; \\ Lisiane Pereira de Jesus ${ }^{2}$; Valéria Ana Corvalã dos Santos ${ }^{1}$; Isabela de Ceni ${ }^{1}$; \\ Luciano da Silva Cabral ${ }^{*}$
}

\begin{abstract}
The study was carried out in a greenhouse with a $4 \mathrm{X} 4$ factorial arrangement randomized block design in order to evaluate the effects of nitrogen rates $\left(0,50,100\right.$ and $\left.150 \mathrm{mg} \mathrm{dm}^{-3}\right)$ associated with cutting heights $(10,15,20$ and $25 \mathrm{~cm})$ on dry matter production and the chemical composition of Massai grass. The seeding was done in pots with $11 \mathrm{~kg}$ of soil. 10 plants were kept per pot, and there were two cuts every 35 days. Nitrogen fertilization was split between the two cuts, where the first $\mathrm{N}$ application occurred after the uniformity cut and the second after the first cut. In each cut the plants were separated and weighed for botanical component evaluation: leaf blade and stem + sheath. After this, the samples were homogenized and analysed for dry matter (DM), crude protein (CP) and neutral detergent fibre (NDF) content. In the first cut, the $\mathrm{N}$ fertilization caused a linear increase in DM production of 0.058 $\mathrm{g} \mathrm{pot}^{-1}$ per each $1 \mathrm{mg} \mathrm{dm}^{-3}$ of $\mathrm{N}$ applied, as well as causing an increase of $0.549 \%$ in CP percentage, a 0.0124 pot $^{-1} \mathrm{~g}$ increase in CP production and a reduction of $0.055 \%$ in NDF. In the second cut, $\mathrm{N}$ rates promoted a quadratic effect on DM production. A maximum DM production of $16.48 \mathrm{~g} \mathrm{pot}^{-1}$ with 107.27 $\mathrm{mg} \mathrm{dm}^{-3}$ of $\mathrm{N}$ was observed while CP production content was increased by $0.0092 \mathrm{~g} \mathrm{pot}^{-1}$ for each $1 \mathrm{mg}$ $\mathrm{dm}^{-3} \mathrm{~N}$ applied. In terms of linear responses to DM and PB, as well as the use efficiency calculated for Massai grass, recommended $\mathrm{N}$ doses range between 50 and $100 \mathrm{~g} \mathrm{dm}^{-3}$.
\end{abstract}

Key words: Defoliation. Fertilization. Management. Panicum maximum cv. Massai.

\section{Resumo}

O estudo foi conduzido em casa de vegetação, considerando delineamento em blocos casualizados em arranjo fatorial 4X4, para avaliar os efeitos de quatro doses de $\mathrm{N}\left(0,50,100\right.$ e $\left.150 \mathrm{mg} \mathrm{dm}^{-3}\right)$ combinadas a quatro alturas de resíduo de corte $(10,15,20$ e $25 \mathrm{~cm})$ e seu efeito sobre a produção de matéria seca e a composição bromatológica do capim Massai. A semeadura foi realizada em vasos com $11 \mathrm{~kg}$ de solo, permanecendo após o desbaste, 10 plantas por vaso, nas quais foram realizados dois cortes a cada 35 dias. A adubação nitrogenada foi parcelada entre os dois cortes, a primeira aplicação de $\mathrm{N}$ ocorreu após o corte de uniformização e a segunda após o primeiro corte. No momento do corte as plantas

\footnotetext{
${ }^{1}$ Discentes de Pós-Graduação, Curso de Mestrado ou Doutorado, Faculdade de Agronomia, Medicina Veterinária e Zootecnia, Universidade Federal de Mato Grosso, UFMT, Cuiabá, MT, Brasil. E-mail: giselleabadia@gmail.com; leni_rlima@hotmail.com; joelson.silva@hotmail.com; val_zoo@yahoo.com.br; isaceni@hotmail.com

2 Profs., Faculdade de Agronomia, Medicina Veterinária e Zootecnia, UFMT, Cuiabá, MT, Brasil. E-mail: galatirosemarylais@ gmail.com; joanisz@yahoo.com.br; joadil@terra.com.br; lisiane.jesus@ig.com.br; lucianoufmt@gmail.com

* Author for correspondence
} 
foram separadas e pesadas nos componentes botânicos de parte aérea: lâmina foliar e colmo+bainha. As amostras foram submetidas às análises de matéria seca (MS), proteína bruta (PB) e fibra em detergente neutro (FDN). No primeiro corte para cada $1 \mathrm{mg} \mathrm{dm}^{-3}$ de $\mathrm{N}$ aplicado foi observado aumento na produção de MS da parte aérea em $0,058 \mathrm{~g}_{\text {vaso }}{ }^{-1}, 0,549 \%$ de incremento no teor PB e $0,0124 \mathrm{~g}_{\text {vaso }}{ }^{-1}$ de aumento na quantidade de PB, bem como redução de $0,055 \%$ no teor de FDN. No segundo corte a máxima produção de MS da parte aérea foi de $16,48 \mathrm{~g} \mathrm{vaso}^{-1}$ com 107,27 $\mathrm{mg} \mathrm{dm}^{-3}$ de $\mathrm{N}$ e a produção de $\mathrm{PB}$ aumentou $0,0092 \mathrm{~g}$ vaso $^{-1}$ para cada $1 \mathrm{mg} \mathrm{dm}^{-3}$ de $\mathrm{N}$ aplicado. Considerando as respostas lineares para produção de MS e PB, bem como a eficiência de uso calculado para o capim Massai, recomendam-se doses de $\mathrm{N}$ variando entre 50 e $100 \mathrm{~g} \mathrm{dm}^{-3}$.

Palavras-chave: Adubação. Desfolhação. Manejo. Panicum maximum cv. Massai.

\section{Introduction}

The Brazilian cattle industry has developed in pasture conditions where forage represents the cheapest nutrient source for grazing animals. Brazil's position as the largest exporter of beef in the world (USDA, 2015) is due to its extensive areas of pasture and favourable climatic conditions. Although grasses belonging to the Brachiaria genera represent the more important grasses cultivated in the central part of Brazil, there is an interest for use of Panicum grasses in order to avoid monoculture and its associated risks, as well as due to it being a way to increase the productivity of these grazing systems.

Panicum maximum Jacq. is one of the most important forage types used for livestock production in tropical and subtropical areas around the world. It presents a high productivity (14 - 33 tons of dry mass of leaves per year), high quality forage (high leaf proportion - $80 \%$ for Tanzania, Mombaça, Tobiatã and Massai grass), as well as high palatability (JANK et al., 2010) and good persistence associated with its resistance to pests and diseases (CORREA; SANTOS, 2003).

However, inadequate management related to stocking rate, forage availability, residue forage mass and leaf area index, as well as an absence of nutrient supply to soil, have been major causes of pasture degradation in the mid-west region of Brazil. According Lavres Junior and Monteiro (2006), around $50 \%$ of the pasture areas present some stage of degradation, where nitrogen deficiency is probably the major nutritional factor limiting the growth and persistence of grasses in the tropics (CECATO et al., 2004). Nitrogen is known to accelerate the formation and growth of new leaves and to increase the vigour of regrowth. There is also its stimulating effect on tillering, which may improve grass recovery after cutting or after defoliation by animals, resulting in higher dry matter production and thus the carrying capacity of pastures.

In 2001, the National Center for Research in Beef Cattle (EMBRAPA) launched the hybrid Panicum maximum cv. Massai, which presents more resistance to acidic conditions, as well as resistance to soils with lower fertility, compared to other cultivars (BRÂNCIO et al., 2003). Thus, the evaluation of this hybrid submitted to different fertilization and management strategies is very important in order to optimize dry matter production and forage quality. In this way, this study was carried out to evaluate the forage production and chemical composition of Massai grass (Panicum cv. Massai) submitted to nitrogen rates and cutting heights.

\section{Material and Methods}

The study was carried out in a greenhouse of the Faculty of Agronomy, Veterinary Medicine and Animal Science of Federal University of Mato Grosso in order to evaluate four nitrogen rates $(0$, 50,100 and $150 \mathrm{mg} \mathrm{dm}^{-3}$ as urea) associated with 
four cutting heights $(10,15,20$ and $25 \mathrm{~cm})$, which were applied to Massai grass (Panicum maximum cv. Massai) by a $4 \mathrm{X} 4$ factorial arrangement using a randomized block design.

The soil used in this trial (collected in a depth ranging from 0 to $20 \mathrm{~cm}$ ) was classified as Oxisol (EMBRAPA, 2006) and presented the following physicochemical characteristics: $\mathrm{pH}=6.6, \mathrm{P}=$ $18.4 \mathrm{mg} \mathrm{dm}^{-3}, \mathrm{~K}=99 \mathrm{mg} \mathrm{dm}^{-3}, \mathrm{H}=0.9$ cmolc dm 3, $\mathrm{Al}^{3+}=0.0 \mathrm{cmolc} \mathrm{dm}^{-3}, \mathrm{Ca}=2.1 \mathrm{cmolc} \mathrm{dm}^{-3}, \mathrm{Mg}$ $=0.8 \mathrm{cmolc} \mathrm{dm}^{-3}$, cation exchange capacity $=4.0$ cmolc dm ${ }^{-3}$, base saturation $=3.2 \mathrm{cmolc} \mathrm{dm}^{-3}$, base saturation $=78.5 \%, \mathrm{OM}=10.2 \mathrm{~g} \mathrm{dm}^{-3}$, clay $=193$ $\mathrm{g} \mathrm{kg}^{-1}$, sand $=723 \mathrm{~g} \mathrm{~kg}^{-1}$ and silt $=84 \mathrm{~g} \mathrm{~kg}^{-1}$. After collection, the soil was dried, kept at a $4 \mathrm{~mm}$ sieve and homogenized and $11 \mathrm{~kg}$ was placed into $15 \mathrm{~kg}$ polyethylene pots.

Sowing was made using $50 \mathrm{~g}$ of seeds per pot, and plant emergence occurred five days later. 10 plants were kept per pot. Pots were irrigated twice daily using distilled water. During the study, daily monitoring of temperature and relative humidity was done, with the following average values observed: $23^{\circ} \mathrm{C}$ and $42^{\circ} \mathrm{C}$ for minimum and maximum temperature and 34 and $88 \%$ for minimum and maximum humidity respectively in the first cut. In the period between the first and second cut, the average values were $20^{\circ} \mathrm{C}$ and $36^{\circ} \mathrm{C}$ for minimum and maximum temperature and 37 and $87 \%$ for minimum and maximum humidity respectively.

Thinning occurred 25 days after sowing. This prompted regrowth at the predetermined residual heights, as measured with a graduated scale from ground level. The first application of $\mathrm{N}$ was made at this time. After 35 days, the first cut and the second nitrogen fertilization for the new growth cycle of 35 days were carried out for the completion of the second cut. The urea used as a nitrogen source was diluted with distilled water according to experimental treatments and applied to the pots.
Two cuts were made with 35 days intervals. The plants from each pot were separated and weighed for a determination of botanical components: leaf blade and stem + sheath. Later, all plant components were dried at $55^{\circ} \mathrm{C}$ for 72 hours. After pre-drying, the plant samples were weighed and ground in a Wiley mill equipped with a $2 \mathrm{~mm}$ mesh sieve. Then, the ground samples were kept in plastic bags for chemical analysis.

At the nutrition animal laboratory, forage samples from each cut were submitted to analysis to determine dry matter (DM) and crude protein (CP) contents according to Silva and Queiroz (2002), and neutral detergent fibre (NDF) was determined according to Cabral et al. (2002) using an autoclave unit.

After the second cut, the roots were removed from the pots and submitted to washing with tap water and sieving. They were then dried in an oven at $55^{\circ} \mathrm{C}$ and weighed to determine the dry matter production of the roots.

The data were analysed using the program SAEG - System Analysis and Statistics Genetics (UFV, 2001), adopting the following statistical model:

$\mathbf{Y}_{\mathrm{ijk}}=\mu+\mathrm{DN}_{\mathrm{i}}+\mathrm{AC}_{\mathrm{j}}+\mathrm{DNi}^{*} \mathrm{ACj}+\mathrm{Bk}+\mathrm{e}_{\mathrm{ijk}}$

where $\mathbf{Y}_{\mathrm{ijk}}=$ observation regarding block $\mathrm{k}$ in nitrogen rate $i$ and the cutting height $j$,

$\mu=$ overall average,

$\mathrm{DN}_{\mathrm{i}}=$ effect of nitrogen rate $\mathrm{i}(\mathrm{i}=1,2,3,4)$,

$\mathrm{AC}_{\mathrm{j}}=$ effect of cutting height $\mathrm{j}(\mathrm{j}=1,2,3,4)$,

$\mathrm{B}_{\mathrm{k}}=$ effect of block $\mathrm{k}(\mathrm{k}=1,2,3)$ and

$\mathrm{e}_{\mathrm{ijk}}=$ random error for each observation.

In order to determine the efficiency of $\mathrm{N}$ use, a linear regression of the reciprocal responses of plants as a function of reciprocal nitrogen supply (N) was performed considering the model of Michaelis-Menten and the diminishing returns law (MITSCHERLICH, 1909) cited by Lana et al. (2005), also known as the transformation of 
Lineweaver-Burk data (LINEWEAVER; BURK, 1934; CHAMPE; HARVEY, 1994), according to the following expression:

$$
1 / \mathrm{Y}=\mathrm{a}+\mathrm{b} *(1 / \mathrm{X})
$$

where $\mathrm{Y}=$ plant responses (production of dry matter x $\left.1000 \mathrm{~kg} \mathrm{ha}^{-1}\right), \mathrm{a}=$ intercept, $\mathrm{b}=$ linear regression coefficient and $\mathrm{X}=$ amount of nutrients $\left(\mathrm{kg} \mathrm{ha}^{-1} \mathrm{yr}^{-1}\right)$. The theoretical maximum production of dry matter (kmax) is obtained by the reciprocal of the intercept (1/a). The amount of nutrients (X) needed to reach half of the maximum theoretical response (ks) is obtained from the above presented model by substituting Y 1/50 x (\%) x 0.01 or by dividing the coefficient by the linear regression intercept (b/The). Fertilizer use efficiency is calculated by dividing the increase in dry matter production (Y2 - Y1) the increase in fertilization (X2 - X1), a specific level of fertilizer compared to the previous level.

In order to extrapolate the results obtained in this study for real conditions (farms), the pot's size and the forage production observed were considered according to $\mathrm{N}$ rates $\left(0,50,100\right.$ and $150 \mathrm{mg} \mathrm{dm}^{-}$ ${ }^{3}$ ), which were equivalent to $0,100,200$ and 300 $\mathrm{kg} \mathrm{ha}^{-1}$ of $\mathrm{N}$. A carrying capacity for grazing beef cattle weighing $450 \mathrm{~kg}$ (1 AU = animal unit) was estimated. Thus, it was assumed that this animal would consume the equivalent of $2.5 \%$ of its body weight per day (dry matter basis), and, to allow it to make selective grazing, this number $(5 \%$ of the PC day $^{-1}$ ) was doubled to offer MS daily.

Additionally, using the equations of BR-Corte (VALADARES FILHO et al., 2010), an estimation of daily weight gains for cattle with $350 \mathrm{~kg}$ of body weight was conducted considering the $\mathrm{CP}$ content in the forage according to $\mathrm{N}$ rates.

\section{Results and Discussion}

There was no interaction between nitrogen (N) and cutting waste heights for the evaluated variables, no effect of cutting waste heights being also found. Therefore, we only studied the effects of nitrogen fertilization.

For the first cut, there was a linear increase $(\mathrm{P}<0.05)$ in shoot $\mathrm{DM}$ production as a function of nitrogen (Figure 1). For each $1 \mathrm{mg} \mathrm{dm}^{-3}$ of $\mathrm{N}$ applied, there was an increase in DM production (DMP) of $0.058 \mathrm{~g} \mathrm{pot}^{-1}$. This increase in production was due to the MS of nitrogen fertilization accelerating growth, tillering and leaf production and, hence, the expansion of the aerial part. In contrast, the same dose of $\mathrm{N}$ in the second cut caused a quadratic effect $(\mathrm{P}<0.05)$ on shoot DM production. Estimated by the equation, the maximum dry matter yield of a $16.68 \mathrm{~g} \mathrm{pot}^{-1}$ dose was $109.1 \mathrm{mg} \mathrm{dm}{ }^{-3}$, which was $248.95 \%$ higher when compared to grass unfertilized with $\mathrm{N}$.

According to Martha Júnior et al. (2004), the production of fodder plants in response to nitrogen fertilization is usually linear within certain limits, which vary mainly with the genetic potential of cultivars. The differences between species in response to applied nitrogen reflect the morphological, physiological and phenological characteristics of the forage plant and the production environment, such as fertilizer, temperature, water supply in the soil, intensity and defoliation frequency. 
Figure 1. Dry matter production of the aerial part $\left(\mathrm{g} \mathrm{pot}^{-1}\right)$ of Massai grass depending on the N levels in cuts 1 (DMPC 1) and 2 (DMPC 2).

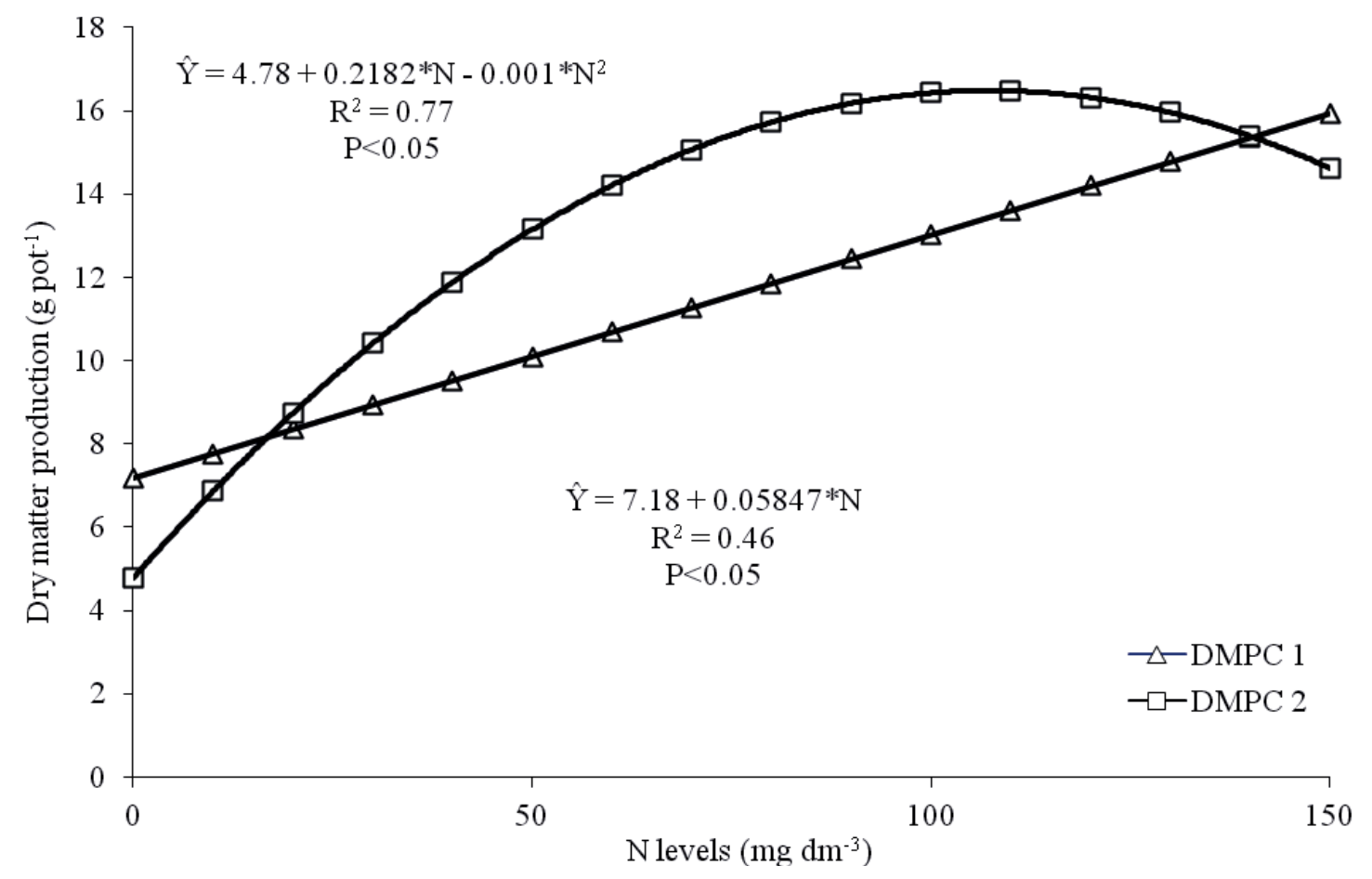

In this study, the quadratic effect of DM production as a function of doses of $\mathrm{N}$ observed in the second cut might be explained by two factors that occurred during the experiment. The first relates to the low temperatures recorded in the period before this cut, thus hampering the development of forage. Low temperatures (below $15^{\circ} \mathrm{C}$ ) in the tropics have been observed as the major cause of seasonality in the growth of tropical grasses (BRYAN; SHARPE, 1965). Another factor that may have also collaborated in the response found in this study is related to the development of inflorescence observed in some plants, especially those receiving higher doses of nitrogen fertilization. There is also the fact that their production begins to decline in the fall, when the reproductive period normally occurs, with the issuance of inflorescence and seed production.

Patês et al. (2008) studied the effects of nitrogen $\left(0,50,100\right.$ and $\left.150 \mathrm{mg} \mathrm{dm}^{-3}\right)$ and phosphorus fertilization ( 0 and $45 \mathrm{mg} \mathrm{dm}^{-3}$ ) on Massai grass, has been observed a quadratic effect of nitrogen rates on dry matter production where the maximum dry matter yield was $26.6 \mathrm{~g} \mathrm{pot}^{-1}$ for a dose of $134.8 \mathrm{mg}$ $\mathrm{dm}^{-3}$.

When conducting a study in a greenhouse to evaluate the performance of different cultivars of Panicum maximum Jacq. (Panicum cv. Massai, Atlas and Tobiatã) receiving different doses of nitrogen fertilization $\left(0,80,160\right.$ and $320 \mathrm{~kg} \mathrm{ha}^{-1}$ $\mathrm{yr}^{-1}$ ), Souza et al. (2006) found that leaf production was influenced by the interaction between farming and doses of $\mathrm{N}$. In addition, the authors observed that only the Massai grass had its production affected by increased nitrogen fertilization, reaching maximum production at a dose of $125 \mathrm{~kg}$ ha ${ }^{-1} \mathrm{~N}$.

A linear increase in DM production at the first cut and a maximum DMP of $107.3 \mathrm{mg} \cdot \mathrm{dm}^{-3}$ at the second cut have been noted, as performed by Lineweaver-Burk analysis (LANA et al., 2005) in order to evaluate the efficiency of fertilization. A 
half maximum response can be estimated at a dose of $54.74 \mathrm{mg} \mathrm{dm}-{ }^{3}$ for the first cut, and $\mathrm{N}$ at 15.69 $\mathrm{mg} \mathrm{dm}{ }^{-3}$ of $\mathrm{N}$ can be estimated for the second cut. Thus, it is noted that nitrogen use efficiency was reduced dramatically with increasing doses (Figure 2). This was seen for the lowest dose $\left(50 \mathrm{mg} \mathrm{dm}^{-}\right.$ $\left.{ }^{3}\right)$ and for the intermediate dose $\left(100 \mathrm{mg} \mathrm{dm}^{-3}\right)$, both reducing the $\mathrm{N}$ use efficiency of the plant by $50 \%$, and also for the highest dose $\left(150 \mathrm{mg} \mathrm{dm}^{-3}\right)$, reducing it by $33 \%$. For the dose of $50 \mathrm{mg} \mathrm{dm}^{-3}$ of $\mathrm{N}$ and $150 \mathrm{mg} \mathrm{dm}^{-3} \mathrm{~N}$, nitrogen use efficiency has been decreased by $66 \%$.

Figure 2. Use efficiency of $\mathrm{N}$ ( $\mathrm{g}$ of $\mathrm{DM}$ produced $\mathrm{mg}^{-1}$ of $\mathrm{N}$ ) for Massai grass the first and second cuts.

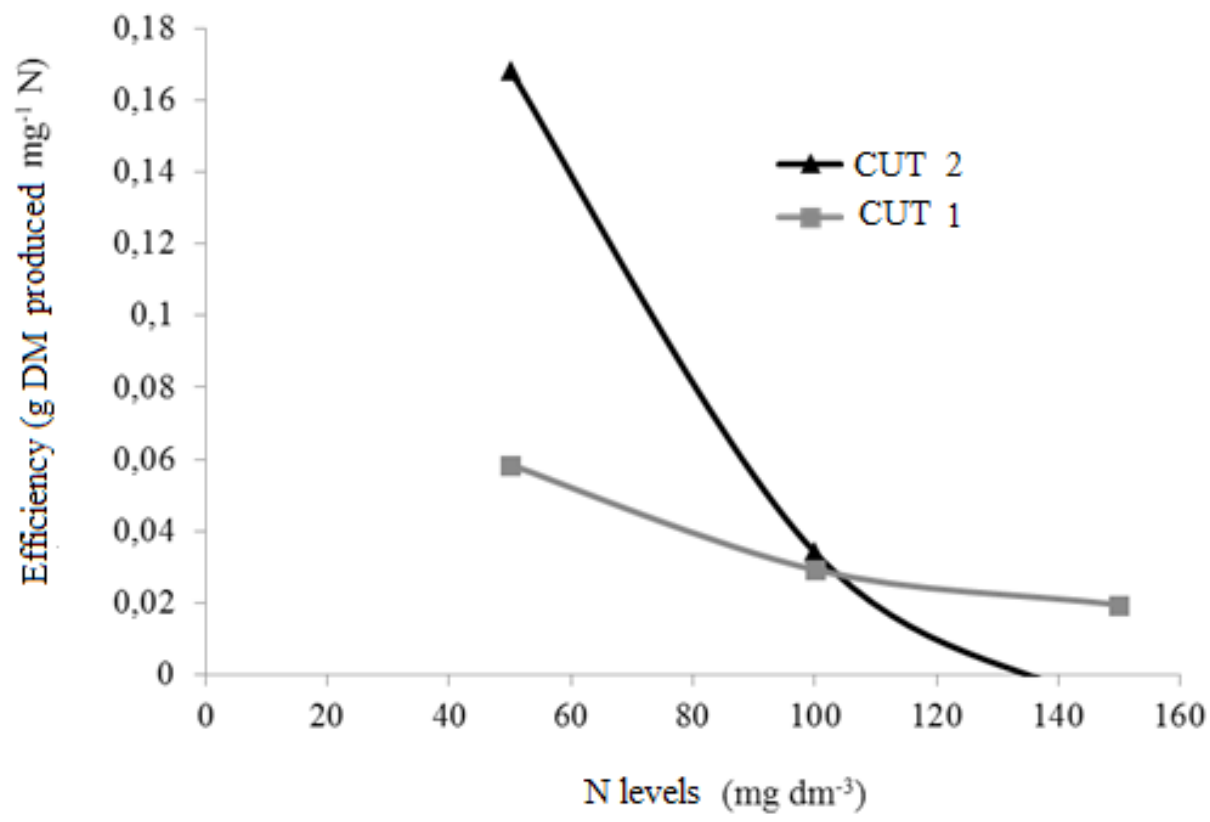

The maximum response of nitrogen use efficiency found for the second cut $(0.17 \mathrm{~g}$ MS produced $\mathrm{mg}^{-1} \mathrm{~N}$ ) was higher in relation to the first cut $\left(0.06 \mathrm{~g}\right.$ MS produced $\left.\mathrm{mg}^{-1} \mathrm{~N}\right)$, which may be attributed to fact that plants on initial growth use most part of its energy for establishment, such as root system and aerial part development. However, in the second period of growth, the plant is already established and there is more root volume to absorb more nutrients, as well as the fact that suffering the action of the cut promotes the induction of basal buds originating new tillers (MEGDA; MONTEIRO, 2015).

Some $\mathrm{N}$ losses can occur every time this nutrient is applied to the ground, being the most common that associated to volatilization, leaching and especially denitrification, which in turn causes a low use efficiency of $\mathrm{N}$. The mentioned authors also suggest that with the use of increasing doses of $\mathrm{N}$, the largest increase in production is obtained proportionally to the first dose applied.

In the first cut, considering the production of MS forage according to $\mathrm{N}$ rates, carrying capacities of 1.46, 2.05, 2.65 and $3.24 \mathrm{AU}^{-1} \mathrm{a}^{-1}$ were estimated. In the second cut, a support capacity of 0.97 was estimated: 2.68, 3.37 and 3.05 $\mathrm{AU}^{\text {ha }}{ }^{-1}$ respectively for $\mathrm{N}$ rates. The increase in the pasture carrying capacity as a function of $\mathrm{N}$ rates, considering the minimum and maximum values estimated at UA $\mathrm{ha}^{-1}$, was $221.92 \%$ and $347.42 \%$ for the first and second cuts respectively. These results are related to the increase in the dry matter production of Massai 
grass due to the use of nitrogen fertilizer, so the mass of fodder to be supplied to animals was significant.

Considering the average of DM production for two cuts, values were estimated for a carrier capacity of 1.6, 3.0, 3.9 and $4.0 \mathrm{ha}^{-1}$ of animals, which clearly demonstrates the benefits of nitrogen fertilization on forage production and the intensification of production per unit area on the property.

A linear increase was observed in the crude protein content of Massai grass as a function of $\mathrm{N}$ rates for both cuts $(\mathrm{P}<0.05)$, with estimated increases of 0.0549 and $0.0439 \%$ of CP for each 1 $\mathrm{mg} \mathrm{dm}{ }^{-3}$ of $\mathrm{N}$ added to the first and second sections respectively (Figure 3). This was probably due to the increased presence of free amino acids and small peptides into plant tissues according the increased of $\mathrm{N}$ in the soil. These results support the claim of Rocha et al. (2002) that the Panicum genus independent grasses in the region have responded to the increased supply of $\mathrm{N}$ in the soil, with positive responses for $\mathrm{CP}$ content. A high $\mathrm{CP}$ concentration in plant fractions in the upper levels of fertilization indicates that nitrogen can be retained in plant tissues, possibly in an inorganic form (MAGALHÃES et al., 2007).

Figure 3. Content of crude protein (\%) of Massai grass depending on the $\mathrm{N}$ levels in cuts 1 (CB C1) and 2 (CB C2).

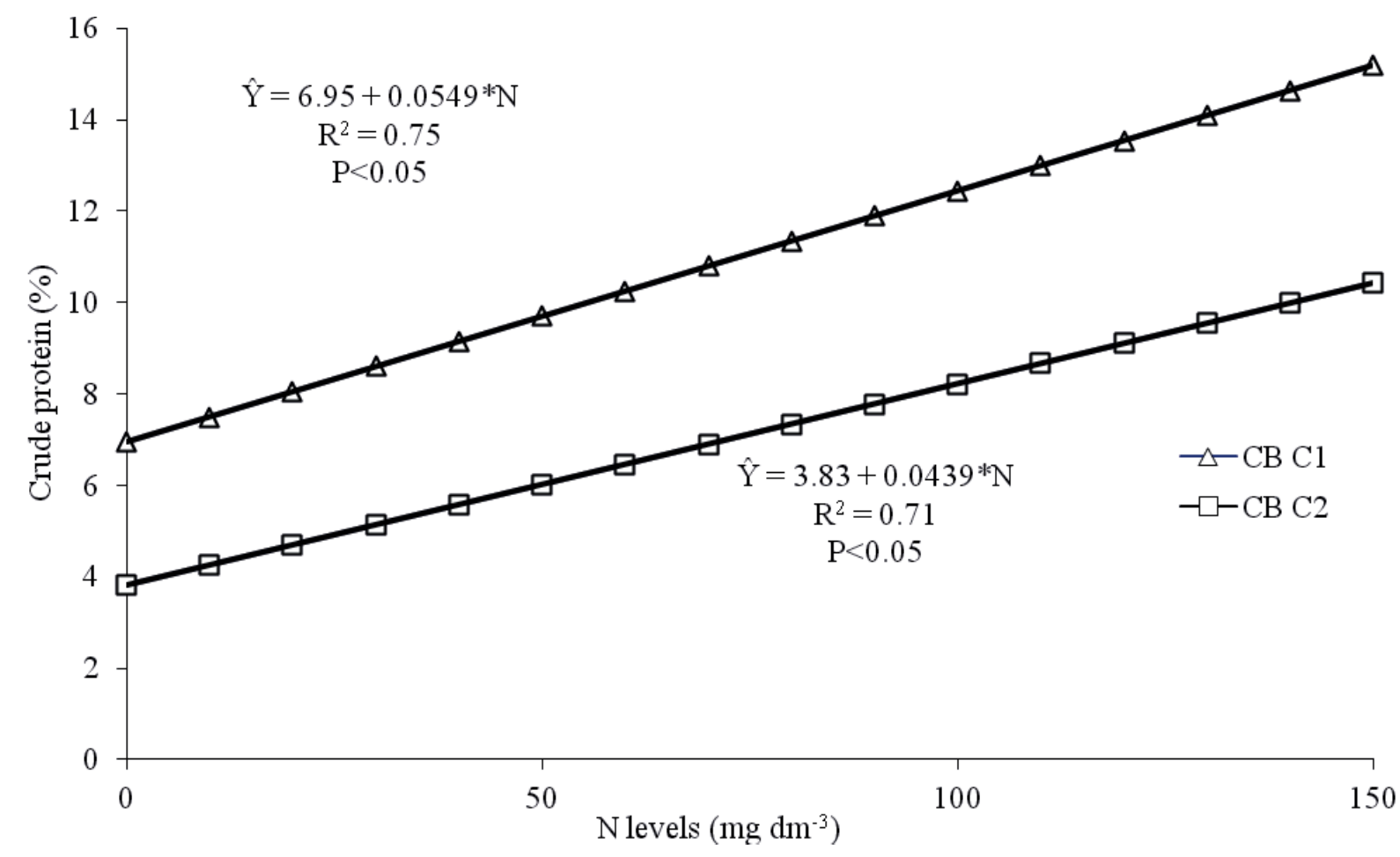

The increases on CP content of forage according nitrogen rates highlights the importance of this technology, not only as means for increase forage production and pasture carrying capacity but also as a strategy to increase the $\mathrm{N}$ supply for animals, which is the major limiting nutrient in tropical conditions especially on dry season.
At a dose of $150 \mathrm{mg} \mathrm{dm}^{-3}, \mathrm{~N}$ was observed in the first cut with a higher content of CP (15.2\%), compared to the second cut $(10.4 \%)$, possibly due to the fact that the first cut tissues were more tender and young because the plants were in the first growth cycle. The reduction in crude protein concentrations depending on the age of plants is an 
important fact to define grazing and forage cycles, aiming thereby to maximize the nutritional value of the food provided to animals. During the period of growth of the plant, the higher the growth period of forage after fertilization, the greater the effect of increased nitrogen in the productivity of the dry mass and the lower the concentration of crude protein (dilution effect).

Van Soest (1994) suggested that ruminant diets should content at minimum $7 \%$ of crude protein in order for not limit rumen microbial growth. Thus, it may be inferred that for the first cut all $\mathrm{N}$ rates would achieve this goal, with values of 7.0, 9.7, 12.4 and $15.2 \% \mathrm{CP}$ estimated from the regression equation for $\mathrm{N}$ doses of $0,50,100$ and $150 \mathrm{mg} \mathrm{dm}^{-3}$ respectively. However, with only 2 doses of 100 $\mathrm{mg} \mathrm{dm}{ }^{-3}$ of $\mathrm{N}$, the cut would meet this need with estimated values of 3.8, 6.0, 8.2 and $10.4 \% \mathrm{CP}$ for doses of $0,50,100$ and $150 \mathrm{mg} \mathrm{dm}^{-3}$ in the same order. Based on the above, nitrogen fertilizer not only affects the production of dry matter and pasture carrying capacity but also the content of PB and the ability to meet the requirements of $\mathrm{N}$ ruminal microflora for animals.

Sampaio et al. (2010) however suggested 10\% of $\mathrm{CP}$ in the diet for animals raised in tropical conditions in order to optimize use of low quality forage. Thus, it could be infer that CP content of Massai grass in the first (zero and $50 \mathrm{mg} \mathrm{dm}^{-3}$ of $\mathrm{N})$ and second cut $\left(0,50\right.$ and $100 \mathrm{mg} \mathrm{dm}^{-3}$ of $\left.\mathrm{N}\right)$ would be inadequate to provide $\mathrm{N}$ for maximum use of forage ingested by grazing animals.

Souza et al. (2006), evaluating aspects related to the nutritional value of Panicum maximum cultivars, observed a significant effect of nitrogen fertilization on the concentration of crude protein in animal feed, with a positive linear response corresponding to increased nitrogen levels. Euclides et al. (2007) evaluated the grass sward characteristics of Tanzania fertilized with nitrogen in late summer and found no significant effect of nitrogen fertilization on the concentration of crude protein in the dry matter forage. They justified this response as a function of the applied nitrogen $\left(50 \mathrm{~kg} \mathrm{ha}^{-1}\right)$ being low, as any effect of nitrogen on the nutritive value of the plant would be diluted when the results were grouped by wet and dry periods. In late summer, profound changes can occur in sward structure, depending on the plant ripening process, that are associated with climatic effects that determine growth in the stem and the senescence stretching process.

Considering that crude protein is the major limiting factor affecting performance of grazing ruminants in the tropical conditions (SAMPAIO et al., 2010), it was performed a simulation of the effects of nitrogen fertilization on estimated daily weight gains using guidelines presented by $\mathrm{Br}$ Corte (VALADARES FILHO et al., 2010) for beef cattle with $350 \mathrm{~kg}$ of body weight. Thus, for the first cut, considering the CP levels observed for Massai grass at dosages of $0,50,100$ and $150 \mathrm{mg} \mathrm{dm}^{-3}$ of $6.96,9.71,12.45$ and $15.20 \%$ (in dry matter), the allowed maintenance performance would be 0.50 , 0.75 and $1.25 \mathrm{~kg}$ rat day ${ }^{-1}$ respectively. It can be noted that the last estimated value for average daily gain $(1.25 \mathrm{~kg})$ has not been commonly observed in experiments with cattle grazing tropical forages. In the second cut, the estimated values were zero, 0.25 and $0.50 \mathrm{~kg}^{-\mathrm{day}^{-1}}$ for the same previously mentioned doses.

When is considered the average daily gain (ADG) estimated for each cut and respective carrying capacity previously estimated (1.6, 3.0, 3.9 and 4.0 $\mathrm{ha}^{-1}$ animals), the obtained values are $0,53,135$ and $248 \mathrm{~kg} \mathrm{ha}^{-1}$ for the production of meat ha-1 for a period of 70 days grazing ( 2 cuts). Thus, one can see that nitrogen fertilization promotes increased production per ha-1 of meat. This benefits the rate of stocking and the daily weight gain of animals, when compared to the traditional system, that is, without the application of $\mathrm{N}$.

For the production of crude protein for Massai grass, a linear increase was observed $(\mathrm{P}<0.05)$ in the levels of nitrogen in the two cuts performed. The 
highest yields were obtained at the first cut, which increased by $0.0124 \mathrm{~g}_{\text {pot }} \mathrm{PB}^{-1}$ for each $1 \mathrm{mg} \mathrm{dm}^{-3}$ of $\mathrm{N}$ added, while, for the second cut, this increase was 0.0093 pot $\mathrm{PB}^{-1} \mathrm{~g}$ per $1 \mathrm{mg} \mathrm{dm}{ }^{-3} \mathrm{~N}$ (Figure 4).
This may be justified due to nitrogen's role in the constitution of proteins, actively participating in the synthesis of organic compounds essential to the metabolism of forage plants.

Figure 4. Crude protein production $\left(\mathrm{mg} \mathrm{pot}^{-1}\right)$ for Massai grass depending on the N levels in cuts 1 (CBP C1) and 2 (CBP C2).

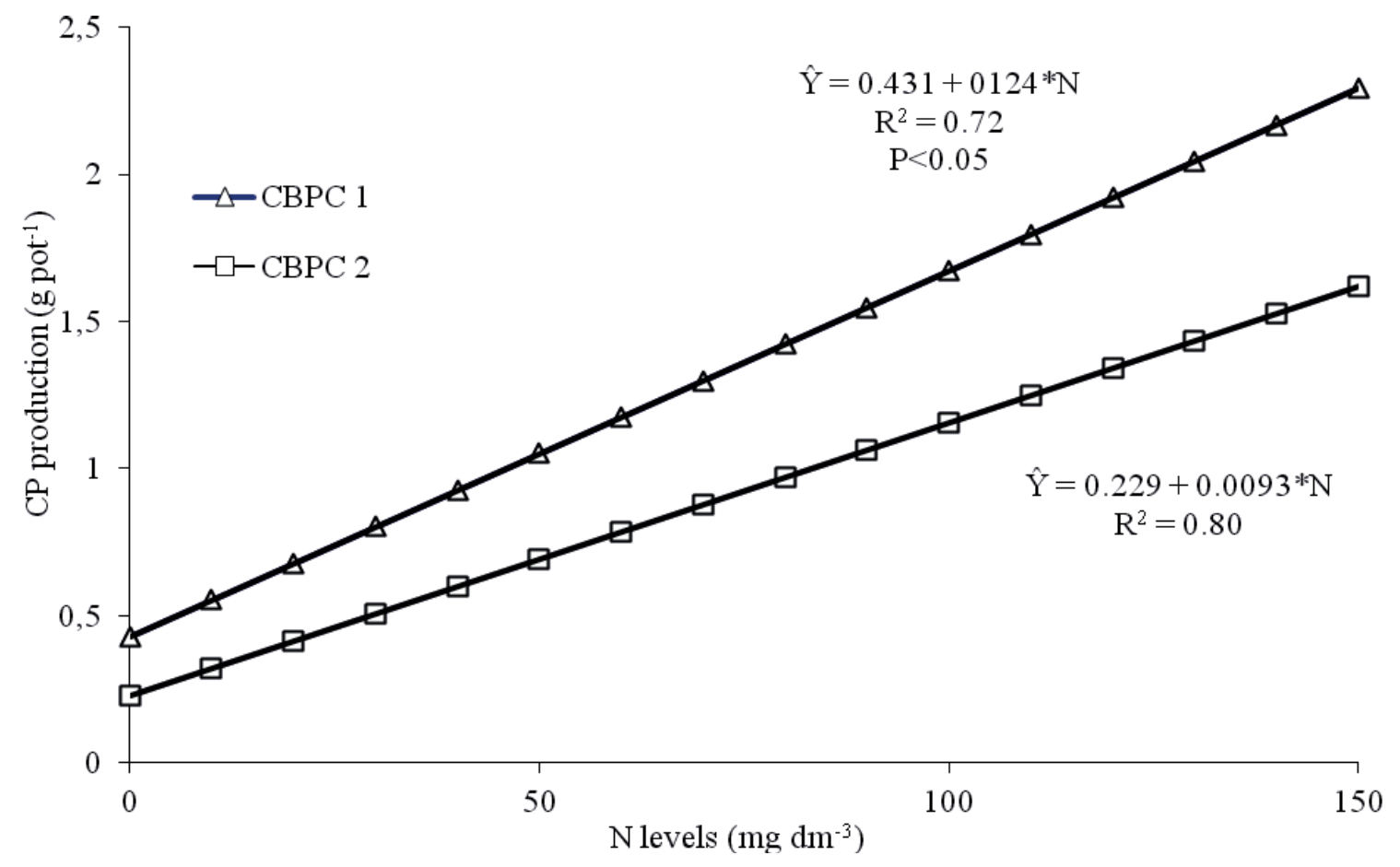

The application of nitrogen affects the NDF differently for the two cuts for Massai grass. For the first cut, a negative linear effect $(\mathrm{P}<0.05)$ was found in which, for each $1 \mathrm{mg} \mathrm{dm}-3$ of $\mathrm{N}$ applied, a reduction of $0.055 \%$ for Massai grass NDF (Figure 5) was identified. The adjusted means were 77.1 and $68.8 \%$ respectively at the dose of 0 $\mathrm{mg} \mathrm{dm}{ }^{-3}$ and the maximum dose studied, showing a reduction of $10.7 \%$ in relation to the dose of 0 $\mathrm{mg} \mathrm{dm}{ }^{-3}$.

This reduction in NDF with increasing in nitrogen rates is very important for improving the nutritional value of forage and the increased consumption of dry matter by animals because
FDN is an important parameter that defines the quality of forage and limits the intake capacity of animals.

Costa et al. (2007) evaluated levels of nitrogen in the chemical composition of Marandu grass in a moderate stage of degradation and observed a reduction in NDF with an increase in nitrogen with the results adjusted by a linear regression model. The average, adjusted by the regression equation, was between 70.44 and $64.15 \%$ respectively for the witness and the maximum dose studied in the three years evaluated. A lower NDF value was obtained in a nitrogen dose of $300 \mathrm{~kg} \mathrm{ha}^{-1}$, with a reduction of $8.93 \%$ compared to the control. 
Figure 5. Content NDF (\%) of Massai grass according to N levels in cuts 1 (NDF C 1) and 2 (NDF C2).

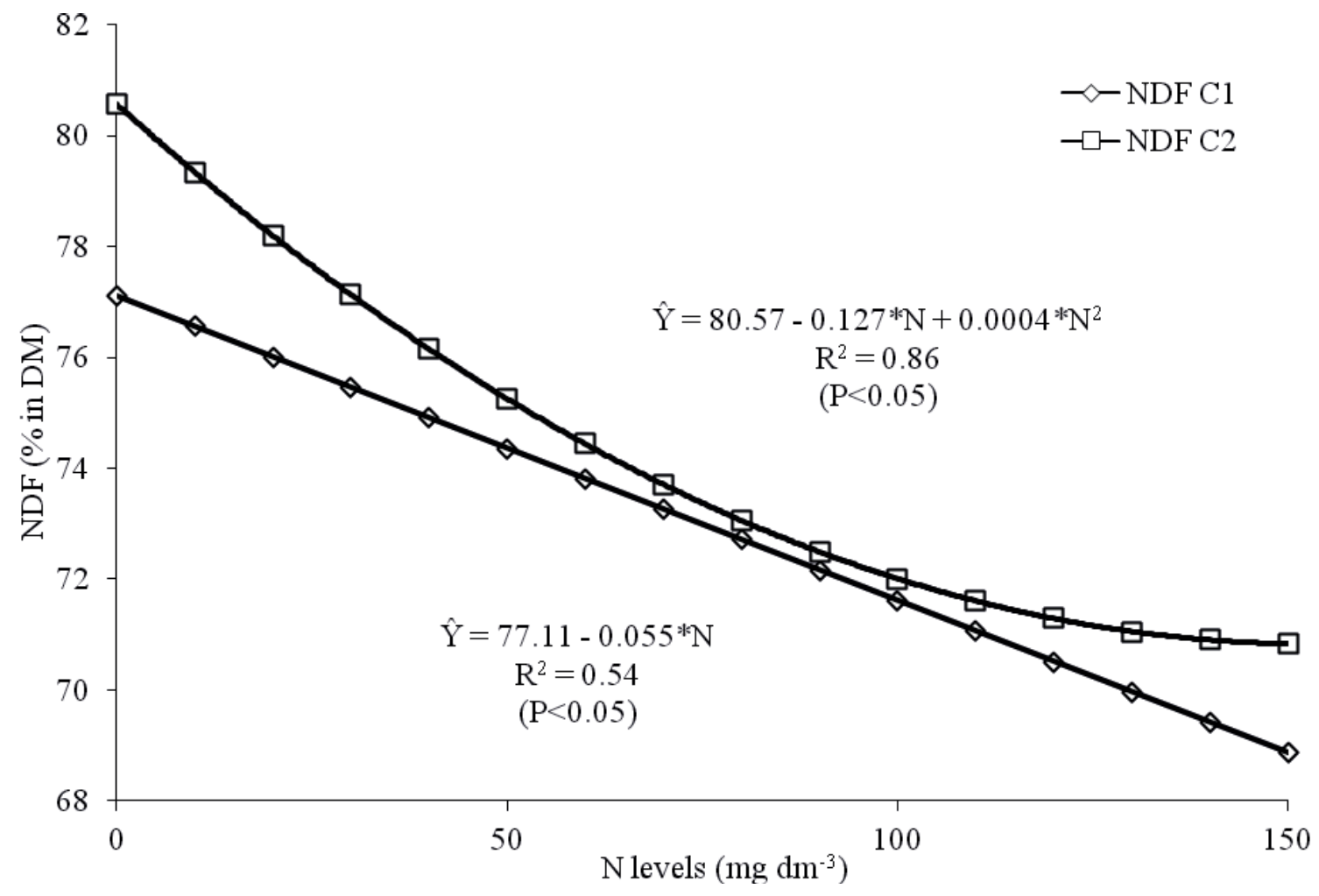

According to Souza et al. (2006), NDF was influenced by cultivars of Panicum maximum and nitrogen fertilization. NDF decreased with the increase in nitrogen, and, for $1 \mathrm{~kg}$ of $\mathrm{N}$ applied, NDF was reduced by $2 \%$. According to Van Soest (1994), the increase in the supply of nitrogen to plants provides an increase in the concentration of proteins in the cellular content and has a dilution effect on cell wall components, reducing the concentration of NDF.

NDF for Massai grass, a commonly found tropical grass developed especially under high temperature conditions, rapidly increases cell wall constituents, which may cause limitations for their use. According to Van Soest (1994), NDF has a stronger association with the intake, fill rate and passage of food in the digestive system of ruminants.

\section{Conclusions}

Nitrogen fertilization promotes an increase in dry matter production and content, the production of crude protein and the reduction of NDF for the first linear cut of Massai grass.

In the second cut, the maximum yield is $16.48 \mathrm{~g}$ pot $^{-1}$ for the level of $107.27 \mathrm{mg} \mathrm{dm}{ }^{-3}$ of $\mathrm{N}$, and the maximum production of roots is obtained at a dose of $82.34 \mathrm{mg} \mathrm{dm}^{-3} \mathrm{~N}$.

Considering the linear response for the production of MS and $\mathrm{PB}$, the increase in $\mathrm{N}$ rates enables higher daily live weight gains due to the increase of mass production and improvement in the chemical composition of Massai grass for fertilizer. 


\section{References}

BRÂNCIO, P. A.; NASCIMENTO JUNIOR, D. N.; EUCLIDES, V. P. B.; FONSECA, D. M.; ALMEIDA, R. G.; MACEDO, M. C. M.; BARBOSA, R. A. Evaluation of three varieties of Panicum maximum jacq. under grazing: diet composition, dry matter intake and animal weight gain. Revista Brasileira de Zootecnia, Viçosa, MG, v. 32, n. 5, p. 1037-1044, 2003.

BRYAN, W. W.; SHARPE, J. P. The effect of urea and cutting treatments on the production of Pangola grass in southeastern Queensland. Australian Journal of Experimental Agriculture and Animal Husbandry, Melbourne, v. 5, n. 19, p. 433-441, 1965.

CABRAL, L. S.; VALADARES FILHO, S. C.; DETMANN, E.; ZERVOUDAKIS, J. T.; PEREIRA, O. G.; VELOSO, R. G.; PEREIRA, E. S. Ruminal kinetic of carbohydrate fractions, gas production, dry matter in vitro digestibility and estimated TDN of corn silage with different grain proportions. Revista Brasileira de Zootecnia, Viçosa, MG, v. 31, n. 6, p. 2332-2339, 2002.

CECATO, U.; DIAS, F. J.; BRANCO, A. F.; SANTELLO, G. A.; JOBIM, C. C. Influence of nitrogen and phosphorus fertilization on the chemical composition of marandu grass (Brachiaria brizantha (Hochts) Stapf cv. Marandu). Acta Scientiarum. Animal Sciences, Maringá, v. 26, n. 3, p. 409-416, 2004.

CHAMPE, P. C.; HARVEY, R. A. Biochemistry. $2^{\text {th }}$ ed. Philadelphia: J. B. Lippincott Company, 1994. 443 p.

CORRÊA, L. A.; SANTOS, P. M. Manejo e utilização de plantas forrageiras dos gêneros Panicum, Brachiaria e Cynodon. São Carlos: Embrapa Pecuária Sudeste, 2003. 36 p. (Documentos, 34).

COSTA, K. A. P.; FAQUIN, V.; OLIVEIRA, I. P.; RODRIGUES, R. B.; MEDEIROS, L. S. Doses e fontes de nitrogênio na composição bromatológica de Brachiaria brizantha cv. Marandu em estágio moderado de degradação. In: REUNIÃO ANUAL DA SOCIEDADE BRASILEIRA DE ZOOTECNIA, 2007, Jaboticabal. Anais... Jaboticabal: SBZ, 2007. v. 44, p. 56-61.

EMPRESA BRASILEIRA DE PESQUISA AGROPECUÁRIA - EMBRAPA. Centro Nacional de Pesquisa de Solos. Sistema brasileiro de classificação de solos. 2. ed. Rio de Janeiro: Embrapa - SPI, 2006. 412 p.

EUCLIDES, V. P. B.; MACEDO, M. C. M.; ZIMMER, A. H.; MEDEIROS, R. N.; OLIVEIRA, M. P. Características do pasto de capim-tanzânia adubado com nitrogênio no final do verão. Pesquisa Agropecuária Brasileira, Brasília, v. 42, n. 8, p. 1189-1198, 2007.
JANK, L.; MARTUSCELLO, J. A.; EUCLIDES, V. P. B.; VALLE, C. B.; RESENDE, R. M. S. Panicum maximum. In: FONSECA, D. M.; MARTUSCELLO, J. A. (Ed.). Plantas forrageiras. Viçosa, MG: Universidade Federal de Viçosa, 2010. p. 167-196.

LANA, R. P.; GOES, R. H. T. B.; MOREIRA, L. M. Application of Lineweaver-Burk data transformation to explain animal and plant performance as a function of nutrient supply. Livestock Production Science, Boston, v. 98, n. 3, p. 219-224, 2005.

LAVRES JUNIOR, J.; MONTEIRO, F. A. Nitrogen nutritional status in Aruana grass in a controlled environment. Revista Brasileira de Ciência do Solo, Viçosa, MG, v. 30, n. 5, p. 829-837, 2006.

LINEWEAVER, H.; BURK, D. The determination of enzyme dissociation constants. Journal of the American Chemical Society, Washington, v. 56, n. 3, p. 658-666, 1934.

MAGALHÃES, A. F.; PIRES, A. J. V.; CARVALHO, G. G. P.; SILVA, F. F.; SOUSA, R. S.; VELOSO, C. M. Influence of nitrogen and phosphorus on Brachiaria decumbens stapf. production. Revista Brasileira de Zootecnia, Viçosa, MG, v. 36, n. 5, p. 1240-1246, 2007.

MARTHA JÚNIOR, G. B.; CORSI, M.; BARIONI, L. G.; VILELA, L. Grazing intensity on herbage production of irrigated Tanzania grass pasture during the spring and summer. Pesquisa Agropecuária Brasileira, Brasília, DF, v. 39, n. 9, p. 927-936, 2004.

MEGDA, M. M.; MONTEIRO, F. A. Marandu Palisadegrass mineral nutrition and production related to nitrogen and potassium supply. Journal of Plant Nutrition, Philadelphia, v. 38, n. 2, p. 289-306, 2015.

MITSCHERLICH, E. A. Das gesetz des minimuns und das gesetz des abnehmenden bodenertrages. Landwirtschaftliche Jahrbücher, Berlim, v. 38, n. 1009, p. 537-552, 1909.

PATÊS, N. M. S.; PIRES, A. J. V.; CARVALHO, G. G. P.; OLIVEIRA, A. C.; FONCÊCA, M. P.; VELOSO, C. M. Production and nutritive value of Tanzania grass fertilized with nitrogen and phosphorus. Revista Brasileira de Zootecnia, Viçosa, MG, v. 37, n. 11, p. 1934-1939, 2008.

ROCHA, P. G.; EVANGELISTA, A. R.; LIMA, J. A.; ROSA, B. Nitrogen doses on grasses of the Cynodon genus. Ciência Animal Brasileira, Goiânia, v. 3, n. 1, p. 1-10, 2002. 
SAMPAIO, C. B.; DETMANN, E.; PAULINO, M. F.; VALADARES FILHO, S. C.; SOUZA, M. A.; LAZZARINI, I.; PAULINO, P. V. R.; QUEIROZ, A. C. Intake, digestibility and rumen dynamics of neutral detergent fibre in cattle fed low-quality tropical forage and supplemented with nitrogen and/or starch. Tropical Animal Health and Production, Almsford, v. 42, n. 6, p. 1471-1479, 2010.

SILVA, D. J.; QUEIROZ, A. C. Análise de alimentos: métodos químicos e biológicos. 3. ed. Viçosa, MG: Editora UFV, 2002. 235 p.

SOUZA, C. G.; SANTOS, M. V. F.; SILVA, M. C.; CUNHA, M. V.; LIRA, M. A. Qualitative measures of Panicum maximum jacq. cultivar under nitrogen fertilization. Revista Caatinga, Mossoró, v. 19, n. 4, p. 333-338, 2006.
UNITED STATES DEPARTMENT OF AGRICULTURE

- USDA. Livestock and poultry: world markets and trade. Washington, DC: Foreign Agricultural Service, 2015. Available at: <http://apps.fas.usda.gov/psdonline/ circulars/livestock poultry.PDF>. Accessed at: 25 jun. 2015.

UNIVERSIDADE FEDERAL DE VIÇOSA - UFV. Sistema de análises estatísticas e genéticas - SAEG. Versão 9.0: Fundação Arthur Bernardes - UFV, Viçosa, MG, 2001.

VALADARES FILHO, S. C.; MARCONDES, M. I.; CHIZZOTTI, M. L.; PAULINO, P. V. R. Exigências Nutricionais de zebuinos puros e cruzados BR-CORTE. 2. ed. Visconde do Rio Branco: Suprema Gráfica e Editora, 2010. v. 1, 193 p.

VAN SOEST, P. J. Nutritional ecology of the ruminant. $2^{\text {th }}$ ed. Ithaca: Comstock Publishing Associates, 1994. 476 p. 